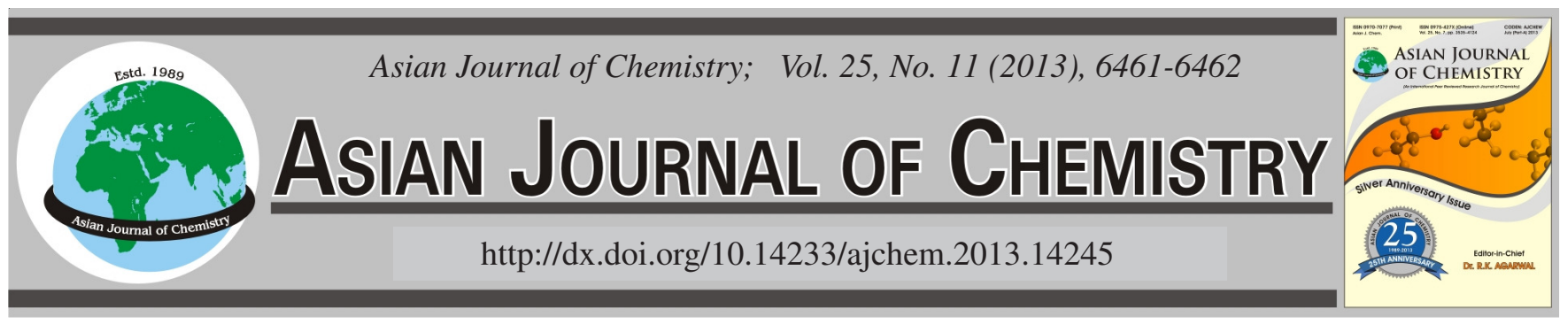

NOTE

\title{
Synthesis and Crystal Structure of \\ Bis[2-((E)-(benzylimino)methyl)-6-bromo-4-chlorophenol]nickel(II)
}

\author{
H.G. ZHANG
}

Department of Chemistry and Chemical Engineering, Baoji University of Arts and Sciences, Shaanxi, P.R. China

Corresponding author: Tel: + 86917 3566589; E-mail: baowenlihuaxue@163.com

(Received: 30 June 2012;

Accepted: 14 May 2013)

AJC-13497

\begin{abstract}
A new nickel(II) complex, $\mathrm{NiL}_{2}$ with the Schiff base ligand $\mathrm{HL}=2$-((E)-(benzylimino)methyl)-6-bromo-4-chlorophenol, has been synthesized and characterized on the basis of elemental analyses and single crystal X-ray diffraction. The complex crystallizes in the monoclinic space group P2(1)/c with the cell parameters $a=10.6405(8) \AA, b=6.01904(3) \AA, c=20.5986(18) \AA, \beta=102.3620(10)^{\circ}, V$ $=1288.65(17) \AA^{3}, Z=2, D_{c}=1.819 \mathrm{~g} / \mathrm{cm}^{3}, \mu\left(M_{\alpha}\right)=7.024 \mathrm{~mm}^{-1}, F_{(000)}=700, \mathrm{~S}=1.036$, the final $\mathrm{R}=0.0590$ and $w R=0.1368$ for 2269 unique reflections $\left(\mathrm{R}_{\mathrm{int}}=0.0428\right)$ with 5879 observed ones $(\mathrm{I}>2 \sigma(\mathrm{I})$ ). The central nickel(II) is four coordinate and bonds to two nitrogen atoms and two oxygen atoms from two Schiff base ligands and the geometry around nickel(II) is a fairly square planar. The packing figure shows that there are no obvious interactions in the units of the complex.
\end{abstract}

Key Words: Nickel(II) Schiff base complexes, Crystal structure, Single crystal X-ray analysis.

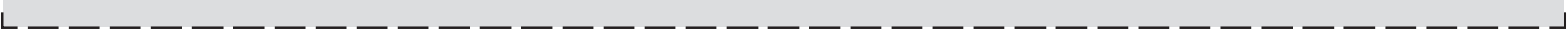

For many years there have been continuous developments and extensive studies on Schiff base coordination compounds ${ }^{1-3}$. Nevertheless, the chemistry of nickel complexes with multidentate Schiff base ligands has attracted huge attention because such complexes play an important role in bioinorganic chemistry and redox enzyme systems and may provide the basis of models for active sites of biological systems or act as catalysts $^{4,5}$. Thus, it is quite important to study the structure of such metal complexes. Recently, we studied the structure of a four coordinate $\mathrm{Ni}$ (II) complex of 2-[(E)-(benzylimino)methyl]6-bromo-4-chlorophenol. In this structure, the Ni(II) ion is four-coordinate with two Schiff base ligands to form a fairly square planar configuration. The purpose of this study was to elucidate the differences in the crystal structures of four-coordinate $\mathrm{Ni}(\mathrm{II})$ complexes of this ligand.

Synthesis: To the vigorously stirred solution of 3-bromo5-chlorosalicylaldehyde (0.2 mmol, $47.2 \mathrm{mg})$ in EtOH (5 mL), was added dropwise a colourless solution of phenylmethanamine ( $0.2 \mathrm{mmol}, 31.4 \mathrm{mg})$ in solution of EtOH $(5 \mathrm{~mL})$ with stirring at room temperature for $1 \mathrm{~h}$. To the resulting orange solution was added $\mathrm{NiCl}_{2} \cdot 6 \mathrm{H}_{2} \mathrm{O}(0.1 \mathrm{mmol}, 23.7 \mathrm{mg})$. The mixture was stirred for $1 \mathrm{~h}$. Green block-shaped crystals of the complex $\mathbf{1}$ grew after 2 weeks (Scheme-I). The product was filtered, washed with EtOH and dried over anhydrous $\mathrm{CaCl}_{2}$ in vacuo overnight. Yield: $75 \%$. Found (\%) C, 49.3; H, 3.2; N, 3.5; $\mathrm{C}_{26} \mathrm{H}_{14} \mathrm{~N}_{2} \mathrm{O}_{2} \mathrm{Br}_{2} \mathrm{Cl}_{4} \mathrm{Cu}$ cacld. (\%): C, 49.0; H, 3.6; N, 3.8.
Crystal structure determination: A crystal of $\mathrm{NiL}_{2}$ was mounted on a glass fiber in a random orientation at room temperature. The data were collected by a Bruker Smart 1000 CCD diffractometer equipped with a graphite-monochromated $\operatorname{MoK}_{\alpha}$ radiation $(\lambda=0.71073 \AA)$ in the range of $1.96 \leq \theta \leq$ 25.02. The structure was solved by direct methods using program SHELXS- $97^{6}$ and refined by full matrix least squares techniques on $\mathrm{F}^{2}$ with SHELXL- $97^{7}$. All the non-hydrogen atoms were refined anisotropically and hydrogen atoms were located at their idealized positions. The crystallographic data, experimental details and parameters of the structure solution and refinement for the complex are summarized in Table- 1 . The main bond distances and bond angles are listed in Table-2. The structural data for the complex was deposited in the Cambridge Crystallographic Data Center under the number CCDC 870017.

The centrosymmetric unit of the title complex (Fig. 1) is a mononuclear complex in which is four coordinate and bonds to two nitrogen atoms and two oxygen atoms from two 2 ((E)(benzylimino) methyl)-6-bromo-4-chlorophenol Schiff bases. In the crystal structure of the complex the atoms of the phenyl ring plane $\mathrm{A}(\mathrm{C}(2) \mathrm{C}(3) \mathrm{C}(4) \mathrm{C}(5) \mathrm{C}(6) \mathrm{C}(7))$ and the chelate ring formed by the same ligand plane $\mathrm{B}((\mathrm{O}(1) / \mathrm{Ni}(1) / \mathrm{N}(1) / \mathrm{C}(1) /$ $\mathrm{C}(2) / \mathrm{C}(3))$ are nearly coplanar with a dihedral angle of 5.4 (3) ${ }^{\circ}$. Because of the conjugation effects through the imino double bond $\mathrm{N}(1)=\mathrm{C}(8)$, the phenyl ring $\mathrm{A}$ and the phenyl 


\begin{tabular}{|c|c|c|c|}
\hline \multicolumn{4}{|c|}{$\begin{array}{c}\text { TABLE-1 } \\
\text { CRYSTAL DATA AND STRUCTURE } \\
\text { REFINEMENT PARAMETERS }\end{array}$} \\
\hline \multicolumn{2}{|c|}{ Properties } & \multicolumn{2}{|c|}{ Complex } \\
\hline \multicolumn{2}{|c|}{ Empirical formula } & \multicolumn{2}{|c|}{$\mathrm{C}_{28} \mathrm{H}_{20} \mathrm{Br}_{2} \mathrm{Cl}_{2} \mathrm{NiN}_{2} \mathrm{O}_{2}$} \\
\hline \multicolumn{2}{|c|}{ Formula weight } & \multicolumn{2}{|c|}{705.89} \\
\hline \multicolumn{2}{|c|}{ Temperature/K } & \multicolumn{2}{|c|}{$298(2)$} \\
\hline \multicolumn{2}{|c|}{ Radiation $\left(\mathrm{MoK}_{\alpha}\right) \lambda(\AA)$} & \multicolumn{2}{|c|}{0.71073} \\
\hline \multicolumn{2}{|c|}{ Crystal shape/colour } & \multicolumn{2}{|c|}{ Block/green } \\
\hline \multicolumn{2}{|c|}{ Crystal size $\left(\mathrm{mm}^{3}\right)$} & \multicolumn{2}{|c|}{$0.45 \mathrm{~mm} \times 0.40 \mathrm{~mm} \times 0.15 \mathrm{~mm}$} \\
\hline \multicolumn{2}{|c|}{ Crystal system } & \multicolumn{2}{|c|}{ Monoclinic } \\
\hline \multicolumn{2}{|c|}{ Space group } & \multicolumn{2}{|c|}{$\mathrm{P}_{2}(1) / \mathrm{c}$} \\
\hline \multicolumn{2}{|c|}{$a(\AA)$} & \multicolumn{2}{|c|}{$10.6405(8)$} \\
\hline \multicolumn{2}{|c|}{$\mathrm{b}(\AA)$} & \multicolumn{2}{|c|}{$6.0190(4)$} \\
\hline \multicolumn{2}{|c|}{$\mathrm{c}(\AA)$} & \multicolumn{2}{|c|}{$20.5986(18)$} \\
\hline \multicolumn{2}{|c|}{$\beta\left({ }^{\circ}\right)$} & \multicolumn{2}{|c|}{$102.3620(10)$} \\
\hline \multicolumn{2}{|c|}{$\mathrm{V}\left(\AA^{3}\right)$} & \multicolumn{2}{|c|}{$1288.65(17)$} \\
\hline & & 2 & \\
\hline$D_{c}(g$ & & 1.819 & \\
\hline$\mu(\mathrm{n}$ & & 4.092 & \\
\hline$F_{(}$ & & 700 & \\
\hline$\theta$ ran & & $1.96 / 25$. & \\
\hline Index ran & $, \mathrm{k}, \mathrm{l})$ & $-12 / 9,-6 / 7$ & $/ 23$ \\
\hline Measured & ctions & 5897 & \\
\hline Observed reflec & {$[I \geq 2 \sigma(I)]$} & 1345 & \\
\hline Data/restrain & rameters & $2269 / 0 / 1$ & \\
\hline Goodness- & ton $\mathrm{F}^{2}$ & 1.036 & \\
\hline $\mathrm{R}_{1}, \mathrm{wR}_{2}[$ & $\sigma(\mathrm{I})]$ & $0.0590 / 0$ & \\
\hline $\mathrm{R}_{1}, \mathrm{wR}_{2}$ & data) & $0.1074 / 0$ & \\
\hline Large diff. peak & hole $\left(\mathrm{e} \AA^{-3}\right)$ & 1.018 and - & \\
\hline $\begin{array}{l}\text { Note: } R_{1}=\Sigma \| F_{o} \\
=1 /\left[\sigma^{2}\left(F_{o}^{2}\right)+(0\right.\end{array}$ & $\begin{array}{l}\mathrm{c} l l / \mathrm{F}_{\mathrm{o}} \mathrm{l}, \mathrm{wR} \mathrm{R}_{2} \\
2 \mathrm{P})^{2}+0.000\end{array}$ & $\begin{array}{l}{\left[\Sigma \mathrm{w}\left(\mathrm{F}_{\mathrm{o}}^{2}-\mathrm{F}_{\mathrm{c}}^{2}\right)^{2} / \Sigma \mathrm{w}\left(\mathrm{F}_{\mathrm{o}}\right.\right.} \\
\mathrm{P}, \mathrm{P}=\left(\mathrm{F}_{\mathrm{o}}^{2}+2 \mathrm{~F}_{\mathrm{c}}^{2}\right) / 3 .\end{array}$ & ${ }^{12}$, where w \\
\hline SELECTED & $\begin{array}{r}\text { TA } \\
\text { ND LENGTI } \\
\end{array}$ & $\begin{array}{l}\text { LE-2 } \\
\text { S (A) AND BOND AI }\end{array}$ & $\operatorname{LES}\left({ }^{\circ}\right)$ \\
\hline Bond & $(\AA)$ & Angle & $\left({ }^{\circ}\right)$ \\
\hline $\mathrm{Ni}(1)-\mathrm{O}(1)$ & $1.848(4)$ & $\mathrm{O}(1)-\mathrm{Ni}(1)-\mathrm{O}(1 \mathrm{~A})$ & $180.0(2)$ \\
\hline $\mathrm{Ni}(1)-\mathrm{O}(1 \mathrm{~A})$ & $1.848(4)$ & $\mathrm{O}(1)-\mathrm{Ni}(1)-\mathrm{N}(1 \mathrm{~A})$ & $87.3(2)$ \\
\hline $\mathrm{Ni}(1)-\mathrm{N}(1 \mathrm{~A})$ & $1.928(5)$ & $\mathrm{O}(1 \mathrm{~A})-\mathrm{Ni}(1)-\mathrm{N}(1 \mathrm{~A})$ & $92.7(2)$ \\
\hline $\mathrm{Ni}(1)-\mathrm{N}(1)$ & $1.928(5)$ & $\mathrm{O}(1)-\mathrm{Ni}(1)-\mathrm{N}(1)$ & $92.7(2)$ \\
\hline $\mathrm{Br}(1)-\mathrm{C}(4)$ & $1.898(7)$ & $\mathrm{O}(1 \mathrm{~A})-\mathrm{Ni}(1)-\mathrm{N}(1)$ & $87.3(2)$ \\
\hline $\mathrm{Cl}(1)-\mathrm{C}(6)$ & $1.737(7)$ & $\mathrm{N}(1)-\mathrm{Ni}(1)-\mathrm{N}(1 \mathrm{~A})$ & $180.0(1)$ \\
\hline
\end{tabular}

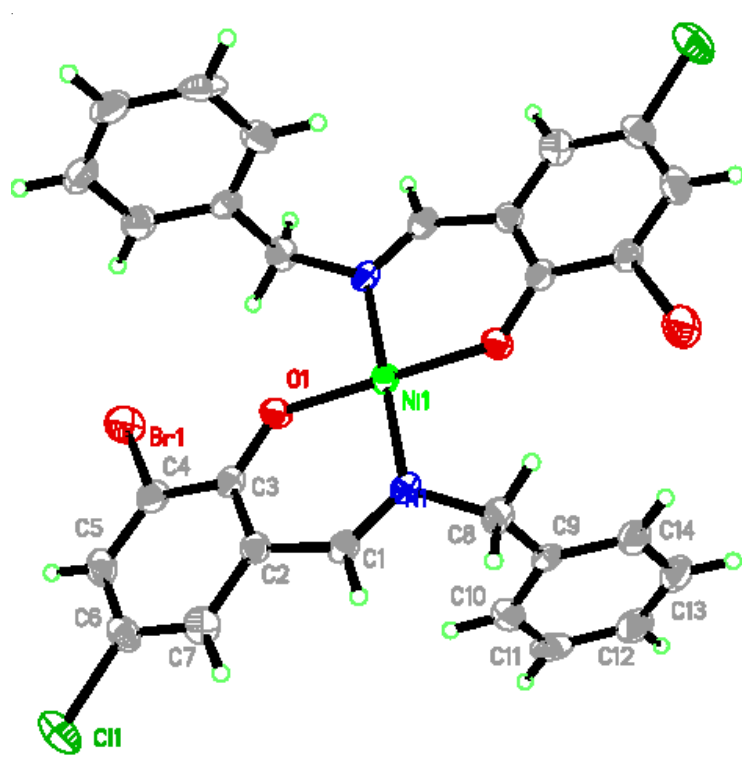

Fig. 1. A view of the complex, showing $30 \%$ probability displacement ellipsoids (symmetry code: A - $\mathrm{x}+1,-\mathrm{y}+1,-\mathrm{z}+1$ )

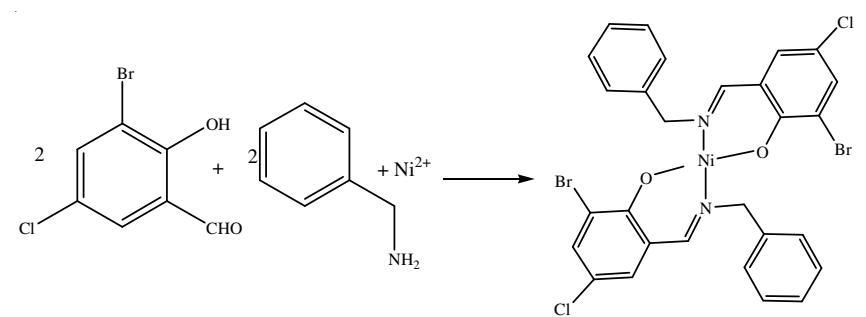

Scheme-I: Synthesis of the complex

ring $\mathrm{B}(\mathrm{C}(9) \mathrm{C}(10) \mathrm{C}(11) \mathrm{C}(12 \mathrm{C}(13) \mathrm{C}(14))$ joined by the $\mathrm{N}(1)$ $=\mathrm{C}(8)$ bond, are non-coplanar (with the dihedral angle 89.8 $\left.(2)^{\circ}\right)$, decreasing the steric effects between the two rings.

The Ni-N (amine) bond distances are 1.928(5) $\AA$, which is significantly shorter than the normal distances. These bond shortenings presumably caused by the electron-withdrawing - $\mathrm{Br}$ and -Cl groups. The Ni-O (amine) distance (1.848(4) $\AA$ ) is quite similar with other reported $\mathrm{Ni}-\mathrm{O}$ distances, as in references $^{8,9}$ mentioned. The values of bond angles around $\mathrm{Ni}(\mathrm{II})$ also indicate that the coordination is pseudo-square planar, with $\mathrm{O}(1 \mathrm{~A})-\mathrm{Ni}(1)-\mathrm{N}(1), \mathrm{O}(1)-\mathrm{Ni}(1)-\mathrm{N}(1)$ and $\mathrm{N}(1 \mathrm{~A})-\mathrm{Ni}(1)-$ $\mathrm{N}(1)$ angles of $87.3(2)^{\circ}, 92.7(2)^{\circ}$ and $180.0(1)^{\circ}$, respectively. (symmetry code: (A) $-\mathrm{x}+1,-\mathrm{y}+1,-\mathrm{z}+1)$. From the packing figure (Fig. 2), we can see that there are no obvious interactions in the units of the complex.

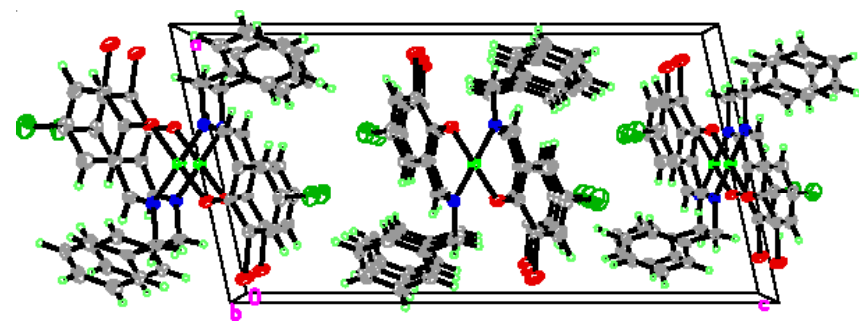

Fig. 2. Packing structure of the complex along the b-axis

In summary, a new asymmetric bidentate nickel(II) complex has been synthesized and characterized by elemental analyses and single-crystal X-ray diffraction.

\section{ACKNOWLEDGEMENTS}

The authors are grateful to the Scientific Research Program of the Education Department of Shaanxi Province for the Research Grant (No. 12JK0630) and the School-Level Key Scientific Research Projects of Baoji University of Arts and Sciences for the Research Grant (No. ZK11062) of P.R. China.

\section{REFERENCES}

1. M. Yamashita, Y. Nonaka, S. Kida, Y. Hamaue and R. Aoki, Inorg. Chim. Acta, 52, 43 (1981).

2. G.G. Mohamed and Z.H. Abd El-Wahab, J. Thermal Anal. Calorim., 73, 347 (2003).

3. G.F. Qi, Z.Y. Yang and B.D. Wang, Transition Met. Chem., 32, 233 (2007).

4. N. Mondal, S. Mitra, V. Gramlich, S.O. Ghodsi and K.M.A. Malik, Polyhedron, 20, 135 (2001).

5. M. Amirnasr, K.J. Schenk, S. Meghdadi and M. Morshedi, Polyhedron, 25, 671 (2006).

6. G.M. Sheldrick, Acta Crystallogr., A46, 467 (1990).

7. G.M. Sheldrick, SHELXTL 97, University of Göttingen, Germany (1997).

8. Z.X. Li, X.L. Zhang and X.H. Pu, Acta Cryst., E64, m202 (2008).

9. S. Basak, S. Sen, S. Mitra, C. Marschner and W.S. Sheldrick, Struct. Chem., 19, 115 (2008).
} 